\title{
Assessment of Farmers' Knowledge and their Perceive Constraints to Recommended Chilli Production Practices in Punjab, India
}

\author{
Parvinder Singh*, B. S. Dhillon and Sukhjinderjit Singh \\ Krishi Vigyan Kendra, Amritsar, India \\ *Corresponding author
}

\section{A B S T R A C T}

\begin{tabular}{|l|}
\hline Ke y w o r d s \\
Knowledge, \\
$\begin{array}{l}\text { Constraints, } \\
\text { Respondents, } \\
\text { Chilli Cultivation }\end{array}$ \\
\hline Article Info \\
\hline $\begin{array}{l}\text { Accepted: } \\
15 \text { July } 2020 \\
\text { Available Online: } \\
10 \text { August } 2020\end{array}$ \\
\hline \hline
\end{tabular}

This study was undertaken to assess the knowledge of recommended practices of chilli cultivation and problems faced by the growers and ex-growers of selected districts of Punjab. A list of chilli growers in each selected village having minimum of half acre of land under chilli was prepared and a proportionate sample of two hundred chilli growers was selected by proportionate random sampling method. In addition to this, all ex-chilli growers were selected from the selected villages. It was found that almost half of the respondents (49.0\%) were of the age group 50-62 years, 53.5 per cent were educated up to middle, 54.5 per cent had an operational land holding ranging from 3-12 acres, 61.5 per cent had area under chilli up to 1 acre, 46.5 per cent had annual income up to Rs. 1, $10,000,58.5$ per cent had experience of chilli cultivation ranging from 1-2 years. Nearly one-third (31.0\%) of respondents had no extension contacts during last year and 47.0 per cent had medium level of scientific orientation. Above $85 \%$ of the respondents had knowledge regarding sowing time, recommended varieties and seed rate. Almost one-third to half of the respondents had knowledge regarding different fertilizer doses, seed treatment, insect-pests and diseases and their control. The major constraints expressed by chilli growers were heavy price fluctuation of the produce and lack of knowledge of raising nursery. The major constraints expressed by ex-chilli growers were comparatively decrease in the production of chilli, intensive requirement of labour at picking and low price at peak time.

\section{Introduction}

Agriculture has been and will continue to be the life line of the Indian economy. As the largest private enterprise in India, agriculture contributes nearly one fourth of the national G.D.P., sustains livelihood of about two third of the population and is the backbone of agrobased industry. In food sector alone, agriculture contributes about 250 thousand crore rupees annually. Through the update of modern agricultural technology, India has moved from an era of chronic food shortage and begging bowl status upto 1960 to food self sufficient and even food exports by the year 1986 when FPO was established. The productivity gain is nearly 3.3 times in food grain, 1.6 times in fruits, 2.1 times in vegetables, 5.6 times in fish, 1.8 times in milk and 4.8 times in eggs (Verma et al., 2015). 
India the 'Land of spices' is the largest producer, consumer and exporter of spices with $40 \%$ share in the world trade. The history of Indian spices dates back to the beginning of the human civilization. Chilli (Capsicum annuum Linn.) is one of the important spice/ vegetable/cash crops grown in India. Chilli also called as red pepper, is also an important condiment crop, grown for its pungent fruits which are used both as green and ripe (red) to impart pungency and color to food. Chilli is a good source of vitamins $\mathrm{A}, \mathrm{C}$ and $\mathrm{E}$. Oleoresins and essential oils of chilli which are the active principals, providing characteristic pungency, flavour and aroma. Chilli popularly known as 'wonder spice' is a major spice as well as vegetable crop grown in many countries. It gained its popularity through more than 400 varieties available all over the world with different pungency, size, shape and colors and its usage. India is the largest producer and consumer of chilli and rich in almost 50 varieties with contribution about $36 \%$ to the total world production. Chilli is an indispensable condiment and used in the daily diet of every Indian household in one or the other form.

Asia produces 65.8 per cent of world green chillies and pepper and stands at the top. India is the largest producer and contributes 25 per cent to total world production (Verma et. al, 2015). India claims to have the spices production of 7.6 million tones, consumption of 6.76 million tonnes and export of 0.84 million tonnes of spices in the world with 5.7 million hectares of land under cultivation. India is meeting approximately $25 \%$ of the world's chilli requirement and considered to be the leader in chilli export followed by China with $24 \%$. Indian chilli exports are mainly influenced by domestic demand and uneven production which is interrupted by erratic monsoon, drought, and yield factor (Anonymous 2014a). Chilli is cultivated in all the states and union territories of the India with Andhra Pradesh leading in both area and production followed by Orissa, Maharashtra, West Bengal, Karnataka, Rajasthan and Tamil Nadu. Chilli cultivation could prove beneficial to the farmers dependent on this crop, if only the farmers take care of certain recommendations regarding technologies involved in the cultivation of this crop.

Punjab ranked nineth in the production of chillies, which is 19.9 thousand tonnes, the area under chilli is also very less which is only 10.6 thousand hectare. So there is a lot of scope of increasing the chilli area. Moreover the yield of chilli in Punjab is 18.77 qtls per hectare which is quite low when compared to package of practices yield (180- 200 qtls per hectare) (Anonymous 2014 b).

The major constraint in the adoption of Chilli cultivation is low prices in the market (Rajput, 2007). Sharma and Gupta, 2010 found that majority of the respondents has knowledge regarding recommended varieties, seed rate and fertilizer doses but the major constraints expressed by chilli growers were erratic price fluctuation of the produce in the market. Lack of technical knowhow, non availability of good quality of inputs at right time, sub-standard and costly chemical fertilizers and pesticides, lack of purchasing power, fear of crop loss etc were expressed as reasons for technological gap in adoption of Chilli cultivation practices. (Biradar, 2012). Considering the importance of adoption of recommended chilli cultivation practices by the farmers, this study was carried out with following objectives include to study the socio-economic characteristics of chilli growers. To study the knowledge of chilli growers regarding recommended chilli cultivation practices and also to study the constraints faced by chilli growers and the exchilli growers who have discontinued the chilli cultivation. 


\section{Materials and Methods}

The study was conducted in Punjab State. The ex-post-facto research design was used for study. Two districts of Punjab namely Amritsar and Tarn Taran were selected on the basis of maximum area and production under chilli crop. From each of district, three blocks and from each block three villages having maximum area under chilli crop were selected, therefore a total number of eighteen villages were selected. All the farmers of eighteen selected villages, who had cultivated chilli in previous year on a minimum of half acre of land constituted the population for the study. A list of chilli growers in each selected village was prepared with the help of local Leaders, sarpanch and Agriculture/ Horticulture development officers. A proportionate random sample of chilli growers from each selected village was taken to make total sample size as 200. Data were collected with the help of structured schedule using interview technique.

\section{Results and Discussion}

\section{Socio-economic characteristics of chilli growers}

The data in Table 1 reveal that 47.5 per cent of the respondents were of the age group 5165 years. It was followed by age group of 36$50(38.0 \%)$ and remaining 14.5 per cent were of age group 25-35 years. The data further reveal that 56.5 per cent of the respondents had education up to middle and 29.5 per cent were illiterates. The data in Table 1 further reveal that 51.0 per cent respondents had operational land holding between 3-12 acres, whereas 37.0 per cent and 12.0 per cent had land holding between 12-23 acres and 23-58 acres respectively. It was found that 61.5 per cent respondents had cultivated chilli on an area of upto 1 acre.
Since chilli cultivation is a skillful enterprise, it might be the reason that respondents having less experience had not taken the risk to cultivate it on more than one acre. The data further revealed that 31.0 per cent respondents cultivated chilli on an area ranging from 1-2 acres. The data in the Table 1 reveal that 45.5 per cent respondents had annual income up to Rs. 1, 10,000 and 36.5 per cent respondents had annual income between Rs. $1,10,000$ to $1,90,000$. The data further depict that 55.5 per cent respondents had experience of chilli cultivation ranging from 1-2 years and 33.5 per cent had experience ranging from 2-4 years. Around one third (32.0 per cent) of the respondents had no extension contacts during last year, whereas 28.5 per cent had contacted the extension workers only once or twice and 24.5 had contacted only 3 times or 4 times.

\section{Knowledge about recommended chilli cultivation practices}

Table 2 reveals that majority of the respondents possessed knowledge with regard to practices like earthing up (99.0\%), sowing time (97.5\%), weeding (93.5\%), recommended varieties $(87.9 \%)$ and seed rate $(85.5 \%)$. Nearly half of the respondents possessed knowledge with regard to practices like phosphorus dose (55.0\%) and F.Y.M. dose $(46.0 \%)$ The reason that could be attributed to the above findings is that chilli cultivation is a skillful and special enterprise and requires specific knowledge. It was also observed that small percentage of the respondents had knowledge about practices like spacing $(21.5 \%)$, diseases, insect-pests and their control (41.0\%), split dose of nitrogen $(31.0 \%)$, seed treatment $(31.0 \%)$ and potassium dose $(30.0 \%)$. The lack of knowledge regarding the percentage of nutrients available in the chemical fertilizers and no or less contact with the extension personnel might be the reasons for the above finding. The above findings are in consonance 
with the findings obtained by Sakharkar (1995) which revealed that respondents were aware of the simple cultivation practices and were not aware of complex practices like seed treatment, fertilizer application and plant protection measures. Similar results have been reported by L.K Sharma and Vinod Gupta, 2010.The knowledge about different aspects of chilli cultivation was studied. The aspects undertaken were recommended varieties, cultural practices, FYM and chemical fertilizer application and plant protection measures. Out of 26 items/ statements in the knowledge test, 4 statements were related to knowledge about recommended varieties, 13 statements were related to knowledge about different cultural practices, 6 statements were related to knowledge about farm yard manure and chemical fertilizer application and 3 statements were related to knowledge about plant protection.

A perusal of the data in Table 3 reveal that the mean knowledge score of the respondents about recommended varieties was 3.48, where as for cultural practices, it was 7.92, for FYM and chemical fertilizer application it was 2.35 .

Table.1 Socio-economic characteristics of chilli growers $(n=200)$

\begin{tabular}{|c|c|c|c|c|}
\hline Sr. No. & Characteristics & Category & Frequency & Percentage \\
\hline \multirow[t]{3}{*}{1.} & \multirow[t]{3}{*}{ Age (years) } & i. $25-35$ & 29 & 14.5 \\
\hline & & ii. $36-50$ & 76 & 38 \\
\hline & & iii. $51-65$ & 95 & 47.5 \\
\hline \multirow[t]{4}{*}{2.} & \multirow[t]{4}{*}{ Education } & i. Illiterate & 59 & 29.5 \\
\hline & & ii. Up to middle & 113 & 56.5 \\
\hline & & iii. High and Senior secondary & 19 & 9.5 \\
\hline & & iv. Above Senior secondary & 9 & 4.5 \\
\hline \multirow[t]{3}{*}{3.} & \multirow{3}{*}{$\begin{array}{ll}\text { Operational } & \text { land } \\
\text { holding (acres) } & \end{array}$} & i. $3-12$ & 102 & 51 \\
\hline & & ii. $>12-23$ & 74 & 37 \\
\hline & & iii. $>23-58$ & 24 & 12 \\
\hline \multirow[t]{3}{*}{4.} & \multirow{3}{*}{$\begin{array}{l}\text { Area under chilli } \\
\text { (acres) }\end{array}$} & i. Up to 1 & 123 & 61.5 \\
\hline & & ii. $>1-2$ & 62 & 31 \\
\hline & & iii. $>2-4$ & 15 & 7.5 \\
\hline \multirow[t]{3}{*}{5.} & \multirow{3}{*}{ Annual income (Rs) } & i. Up to $1,10,000$ & 91 & 45.5 \\
\hline & & ii. $>1,10,000-1,90,000$ & 73 & 36.5 \\
\hline & & iii. Above $1,90,000$ & 36 & 18 \\
\hline \multirow[t]{3}{*}{6.} & \multirow{3}{*}{$\begin{array}{l}\text { Experience of chilli } \\
\text { cultivation (years) }\end{array}$} & i. $1-2$ & 111 & 55.5 \\
\hline & & ii. $>2-4$ & 67 & 33.5 \\
\hline & & iii. $>4-8$ & 22 & 11 \\
\hline \multirow[t]{4}{*}{7.} & \multirow{4}{*}{$\begin{array}{l}\text { Extension visits } \\
\text { (during last year) }\end{array}$} & i. No extension contacts & 64 & 32 \\
\hline & & ii. $1-2$ & 57 & 28.5 \\
\hline & & iii. $3-4$ & 49 & 24.5 \\
\hline & & iv. Above 4 & 30 & 15 \\
\hline \multirow[t]{3}{*}{8.} & \multirow[t]{3}{*}{ Scientific orientation } & i. Low (2-6) & 69 & 34.5 \\
\hline & & ii. Medium (6-10) & 97 & 48.5 \\
\hline & & iii. High (10-12) & 34 & 17 \\
\hline
\end{tabular}


Table.2 Knowledge of the respondents about recommended chilli cultivation practices $(n=200)$

\begin{tabular}{|c|c|c|c|c|c|}
\hline \multirow{3}{*}{$\begin{array}{l}\text { S. } \\
\text { No }\end{array}$} & \multirow[t]{3}{*}{ Cultivation practices } & \multicolumn{4}{|c|}{ Knowledge of recommended practices } \\
\hline & & \multicolumn{2}{|c|}{ Yes } & \multicolumn{2}{|c|}{ No } \\
\hline & & Frequency & Percentage & Frequency & Percentage \\
\hline 1. & Recommended varieties & 174 & 87.0 & 26 & 13.0 \\
\hline 2. & Appropriate Seed rate & 170 & 85.0 & 30 & 15.0 \\
\hline 3. & Seed treatment & 62 & 31.0 & 138 & 69.0 \\
\hline 4. & Appropriate Spacing & 43 & 21.5 & 157 & 78.5 \\
\hline 5. & Appropriate Sowing time & 195 & 97.5 & 5 & 2.5 \\
\hline 6. & $\begin{array}{l}\text { Appropriate Transplanting } \\
\text { time }\end{array}$ & 189 & 94.5 & 11 & 5.5 \\
\hline 7. & Use of Farm yard Manure & 92 & 46.0 & 108 & 54.0 \\
\hline \multirow[t]{4}{*}{8.} & $\begin{array}{l}\text { Appropriate Doses of } \\
\text { chemical fertilizer applied: }\end{array}$ & & & & \\
\hline & Nitrogen & 85 & 42.5 & 115 & 57.5 \\
\hline & Phosphorus & 110 & 55.0 & 90 & 45.0 \\
\hline & Potassium & 60 & 30.0 & 140 & 70.0 \\
\hline 9. & Split dose of nitrogen & 62 & 31.0 & 138 & 69.0 \\
\hline 10. & Earthing up & 198 & 99.0 & 2 & 1.0 \\
\hline 11. & Weeding & 187 & 93.5 & 13 & 6.5 \\
\hline 12. & Control of pests and diseases & 82 & 41.0 & 118 & 49.0 \\
\hline
\end{tabular}

Table.3 Mean knowledge score of the respondents about different aspects of chilli cultivation $(\mathrm{n}=200)$

\begin{tabular}{|c|c|c|c|}
\hline S. No. & Aspects of chilli cultivation & $\begin{array}{l}\text { Max knowledge } \\
\text { score }\end{array}$ & Mean Knowledge score \\
\hline 1 & Use of Recommended varieties & 4 & 3.48 \\
\hline 2 & Cultural practices & 13 & 7.92 \\
\hline 3 & Fertilizer application & 6 & 2.35 \\
\hline 4 & Plant protection measures & 3 & 1.23 \\
\hline
\end{tabular}

Table.4 Distribution of respondents on the basis of their overall knowledge about chilli cultivation $(\mathrm{n}=200)$

\begin{tabular}{|l|l|c|c|}
\hline S. No. & Category (knowledge score) & Frequency & Percentage \\
\hline $\mathbf{1}$ & Low (11) & 58 & 29.0 \\
\hline $\mathbf{2}$ & Medium (16) & 77 & 38.5 \\
\hline $\mathbf{3}$ & High (21-26) & 65 & 32.5 \\
\hline
\end{tabular}


Table.5 Constraints expressed by respondents in chilli cultivation* $(\mathrm{n}=200)$

\begin{tabular}{|l|l|c|c|}
\hline S. No. & Constraint & Frequency & Percentage \\
\hline $\mathbf{1}$ & Erratic price fluctuation of the produce & 147 & 73.5 \\
\hline $\mathbf{2}$ & Lack of knowledge of raising nursery & 135 & 67.5 \\
\hline $\mathbf{3}$ & No support price of chilli & 123 & 61.5 \\
\hline $\mathbf{4}$ & Low remunerative price at peak time & 98 & 49.0 \\
\hline $\mathbf{5}$ & High cost of hybrid seeds & 59 & 29.5 \\
\hline $\mathbf{6}$ & $\begin{array}{l}\text { High infestation of diseases, insect- } \\
\text { pests etc. }\end{array}$ & 42 & 21.0 \\
\hline $\mathbf{7}$ & Non-availability of processing units. & 36 & 18.0 \\
\hline $\mathbf{8}$ & Scarcity of Labour. & 27 & 13.5 \\
\hline
\end{tabular}

* Multiple response

Table.6 Reasons for discontinuance of chilli cultivation* $(n=18)$

\begin{tabular}{|l|l|c|c|}
\hline S. No. & Reasons & Frequency & Percentage \\
\hline $\mathbf{1}$ & $\begin{array}{l}\text { Comparatively decrease in the yield of } \\
\text { hybrid chilli. }\end{array}$ & 17 & 94.4 \\
\hline $\mathbf{2}$ & $\begin{array}{l}\text { Intensive requirement of labour at } \\
\text { picking. }\end{array}$ & 16 & 88.8 \\
\hline $\mathbf{3}$ & Low price at peak time. & 16 & 88.8 \\
\hline $\mathbf{4}$ & High competition in chilli cultivation. & 14 & 77.7 \\
\hline $\mathbf{5}$ & Not a profitable enterprise. & 12 & 66.6 \\
\hline
\end{tabular}

* Multiple response

In plant protection measures, the mean knowledge score was 1.23 . So it is clear from the above findings that the respondents had a fairly high knowledge about recommended varieties, whereas they have medium to low level of knowledge about cultural practices and chemical fertilizer application and plant protection measures. (Sakharkar1995).

\section{Distribution of respondents in various knowledge categories}

Table 4 reveals that 29.0 per cent respondents had low level of knowledge, whereas 38.5 and 32.5 per cent respondents had medium and high level of knowledge respectively regarding recommended chilli cultivation practices. Thus, it could be concluded that two third of the respondents had low to medium level of knowledge. These findings were supported by Salame (2000), Prajapati et. al. (2002) and Sasane (2010). These chilli growers might not have been exposed to the improved technology and as a result only less per cent of them possessed high knowledge with regard to improved practices. Similar results have been reported by Sarker, 2016.

\section{Constraints in chilli cultivation}

The data presented in Table 5 reveal that 73.5 per cent respondents expressed erratic price fluctuation of the produce as the main constraint (Hanumanaikar, 1995). It can be due to the fact that price of chilli ranges from Rs. 5 to Rs. 15 per kg. In the peak season of production it could be Rs. 5 per $\mathrm{kg}$. At this price the farmers are not able to pay their picking charge which is roughly Rs. 2 per kg. More than 60 per cent respondents expressed 
lack of knowledge of nursery raising as major constraint. Since raising nursery for chilli requires special skill, so it is a tough job for farmers. The table further reveal that 61.5 per cent respondents expressed no support price of chilli as main constraint, 49.0 per cent, 29.5 percent and 21.0 per cent respondents expressed low price at peak time, high cost of hybrid seeds and high infestation of diseases, insects pests, as the major constraints, respectively. An effort was also made to find out reasons for discontinuance of chilli cultivation by the farmers. The results presented in Table 6 reveal that 94.4 per cent of respondents expressed comparatively decrease in the yield of chilli as the reason for discontinuance of chilli cultivation. This was due to the fact that for hybrid chilli seed production, minimum isolation distance is to be maintained. But because of the growing number of seed producers, they sometimes may not maintain this distance. Thus, seed impurities can lead to the above findings. Equal percentage of respondents (88.8\%) expressed intensive requirement of labour at picking and low price at peak time as the main reasons for discontinuing chilli cultivation. Similar findings were reported by Tekale et. al., 2010. These two constraints are interlinked as picking in chillli requires intensive labour and if the produce fetches poor return in the market, then chilli cultivation can turn out to be a non-profitable enterprise, which as a constraint was expressed by 66.6 per cent of the respondents. More than 75 per cent of the respondents expressed high competition in chilli as the main reason for discontinuing chilli cultivation.

In conclusion the chilli growers need to be educated regarding the use of treated seeds, maintaining correct spacing and irrigating the crop at the recommended intervals. The farmers need to be educated and motivated to use the correct doses of fertilizers and manures, so that they can get the high returns by reducing the expenditure. The price of chilli depends upon various factors like consumers demand, export and import in national and international market, quantity of production and consumers surplus. Due to the changes in above factors, the price of chilli is fluctuating to a greater extent. Since majority of the respondents expressed low price at peak time, so efforts should be made to develop some processing units so that farmers can sell their produce to these units at the time of glut of produce. Majority of the respondents expressed lack of knowledge of raising nursery as major constraint, so extension personnel should organize method demonstration for nursery raising to improve the knowledge and skills involved.

\section{References}

Anonymous (2014a). Indian Agriculture. Indian Economic Data Research Centre, New Delhi, India.

Anonymous (2014b). Area, Yield and Production of Different Crops. Directorate of Horticulture, Punjab, Chandigarh, India, Unpublished report.

Biradar G.S. (2012). A study on Technological Gap in Adoption of Improved Chilli Cultivation Practices in Yadagir and Raichur Districts of Karnataka. M. Sc. (Agri.) Thesis, Univ. Agric. Sci., Raichur.

Hanumanaikar, R.H. (1995).A study on knowledge adoption and marketing behavior of sunflower in Dharwad district. M.Sc. Thesis. University of Agricultural Sciences, Dharwad, India..

Prajapati, M. R, V. T. Patel, N. V. Chaudhary and M. C Soni, (2002) Constraints experienced by growers in adoption of recommended chilli technology. Gujarat Journal of Extension 
Education, 12-13: 55-58.

Rajput, H.D., S.V. Supe and U.R. Chinchmalatpure (2007). Factors associated for declining Chilli area and its diversification. Indian Res. J. Ext. Edu. 7(2\&3):76

Sakharkar, V.S. (1995). A study on knowledge, fertilizer use pattern and constraints in the cultivation of soyabean by farmers of Nagpur district, Maharashtra. Ph.D. Dissertation, University of Agricultural Sciences, Dharwad, India.

Salame, S. P. (2000). Constraints in adoption of chilli cultivation practices by farmers. M.Sc (Agri.) Thesis, Dr. PDKV Akola.

Sarker MNI (2016). Knowledge, Adoption and Constraint analysis of Chilli Technology in Char Area of Bangladesh. International Journal of Ecology and Development Research, 1(1): $16-18$
Sasane, M. S. (2010). Knowlede and adoption of recommended production technology by cauliflower growers. M. Sc (Agri) Thesis, MAU, Parbhani (MS).

Sharma, L.K and Vinod Gupta (2010). Knowledge and constraints in scientific cultivation of Chilli among the farmers. Raj. J. Extn. Edu. 17: 6064.

Tekale, V. S., N. G. Jalit and C. J. Gaikwad (2013). Adoption of recommended chilli cultivation practices by the farmers. International Journal of Emerging Technologies in Computational and Applied Sciences. 6(3): 235-238

Verma, Sushil Kumar, Rai, D.P. and Verma, Lekh Ram (2015). Knowledge and adoption of recommended chilli production technology by the farmers of Raipur district. Agric. Update, 10(2): 120-125.

\section{How to cite this article:}

Parvinder Singh, B. S. Dhillon and Sukhjinderjit Singh. 2020. Assessment of Farmers' Knowledge and their Perceive Constraints to Recommended Chilli Production Practices in Punjab, India. Int.J.Curr.Microbiol.App.Sci. 9(08): 1423-1430. doi: https://doi.org/10.20546/ijcmas.2020.908.163 